\title{
Reshoring of services and employment
}

\section{Introduction}

During the 1990s and the first decade of the twenty-first century, the offshoring phenomenon extended throughout the world, constituting the most important change in the internationalisation strategies of companies. It transformed the international trade patterns from an exchange based on the specialisation of final consumer goods to a pattern of specialisation based on stages of production (Feenstra, 1998; Feenstra and Hanson, 1996; Campa and Golberg, 1997; Hummels et al. 2001; Blinder, 2006).

Initially, the process was developed through the offshoring of material inputs in the manufacturing sectors from developed countries to emerging economies where comparative advantages existed, mainly in production costs. These processes were characterised by the transfer to less developed countries of the most intensive parts of the value chains requiring low-skilled labour. Meanwhile, the higher added value parts of the value chain, constituting the core business of the companies and intensive in high-skilled labour, remained concentrated in the advanced countries (Zhang, 2003; Fuster et al., 2008; Martínez-Mora and Merino, 2014).

Subsequently, during the first decade of the twenty-first century, the offshoring phenomenon extended to the services activities. In this case the pattern of relocation was modified geographically and also in terms of content. The services activities that are offshored, both in manufacturing and services sectors, are not exclusively carried out in countries with comparative advantages in costs but also and fundamentally in those that guarantee improved efficiency. Companies are increasing offshoring processes of services in developed countries. Not only services with low value added are relocated. Activities that require highly skilled labour are also offshored to other countries, such as services related to ICTs, financial consulting, marketing, accounting management and human resources, energy management, engineering, transport or R\&D, etc. (Contractor, Kumar et al., 2010; Doh et al., 2009).

These activities require highly qualified labour and there is a higher level of specialisation in these tasks in other countries where they are carried out more efficiently or at a lower 
cost. In these cases, the companies seek to develop certain services abroad that complement the activities developed internally in the domestic country. Innovation activities are being broken down into technologically different and separable services that can be developed within or outside the company and in the home country or abroad (Martínez-Moya et al., 2012). Due to the complexity of innovation processes in general, it is difficult for companies to obtain the same level of efficiency in all of the activities that make up the process, which may lead to the contracting of other external companies to undertake some of these activities (Afuah, 2001). Therefore, some companies carry out a service internally while also simultaneously outsourcing it (Parmigiani, 2007; Rothaermel et al., 2006).

For this reason, the companies that implement this strategy usually have higher technological capacities and are larger in size with internal departments that develop activities related to those outsourced abroad (Jabbour and Zuniga, 2016; Tamayo and Huergo, 2016; Musteen, 2016; Holl and Rama, 2014; García-Vega and Huergo, 2011).

Therefore, the strategy of service offshoring has expanded significantly, not only among services companies but also among manufacturing firms, given the increasingly closer links between manufacturing and services. Manufacturing and services are closely related sectors, as industrial companies require a wide range of necessary or complementary services in order to carry out the production of manufactured products. In recent decades, a progressive trend has been observed towards the externalisation of services by manufacturing companies, partially or entirely subcontracting tasks that were previously undertaken in the facilities of the company to firms specialised in services. The progressive externalisation of services and, particularly, activities related to ICTs by industrial companies constitutes one of the reasons why, from the mid 1980s, industry has been gradually losing its importance in the production and labour structure of developed economies and which has also begun to affect developing economies, while services are continually gaining weight. Furthermore, there is an increasingly greater presence of services in the production of manufactured goods. This makes it difficult to make a clear separation between manufacturing and services activities (Pilat and Wölfl, 2005; Nordås and Kim, 2013; Baldwin et al., 2015). This growing role of services as an input of the production of manufactured goods, known as the servicification of manufacturing, is a relevant phenomenon in both developed and developing countries (Lanz and Maurer, 2015). The technological innovations in communications and transport 
explain another increasingly important phenomenon in the global economy, namely the strategy of international fragmentation of production which has given rise to global value chains (GVC) in which many companies from many countries participate, each specialising in a part of the production process. Furthermore, the correct functioning of these GVCs requires a high availability of services. These two strategies, the servicification of manufacturing and the development of GVCs, explain, for example, that services represent approximately half of the exports (both direct exports and input content) of the EU and the USA (OECD, 2014) and that their share of world trade has more than doubled, in detriment to manufactured goods (Gandoy et al., 2018).

Recent economic analysis of International Trade has revealed that offshoring strategies comprising the relocation of certain inputs in the most efficient locations lead to improvements in the well-being of the countries involved (Olsen, 2006; Blinder, 2006; Grossman and Rossi-Hansberg, 2006; Helpman, 2011), as predicted in the Traditional International Trade Theory for the trade of final goods (Ricardo, 1817: Hechscher-Ohlin, 1991; Krugman, 2009). Furthermore, it is known that these strategies are carried out primarily by companies with the highest levels of productivity (Melitz, 2003).

Meanwhile, the International Business literature explains that one of the forces determining the activity of multinational companies is the possession of ownership advantages (innovation, technology, etc.) (Dunning 1980a, 1980b, 1993, 2000). The most recent literature examines the specification of these advantages in depth (Lamb et al. 2011; Ellis, 2011; Laursen et al. 2012). Furthermore, this literature reveals that operating in international markets constitutes an asset for companies, increasing their capacity to advance in their internationalisation processes and enabling them to become multinationals (Johanson and Wiedersheim-Paul, 1975; Johanson and Vahlne, 1977).

From both branches of the literature we can surmise that the effects of the offshoring processes on the level of employment in the countries and the firms implementing them should be positive. First, the gains in well-being demonstrated in the International Trade literature imply economic growth, that is, increases in production and, therefore, the level of employment. And, second, the International Business literature also shows that companies that implement these processes are the most efficient and have the highest capacities and are therefore the most competitive. From this, we can deduce that these companies will be those mostly likely to grow and generate employment. 
In recent years, and after the global financial crisis beginning in 2007, a reversion process of this offshoring strategy, named reshoring, has been observed. This strategy consists in the return to the home country (backshoring) or to countries nearby (nearshoring) of part of the production or activities previously offshored abroad. This new phenomenon began to be detected in manufacturing industries for material inputs and has extended in recent years to the services sector and the activities in the manufacturing and services sectors.

The beginning of these reshoring processes coincided with the collapse of international trade in 2008 and 2009 (Baldwin and Taglioni, 2009), with a slight reduction in their intensity in the following years, associated to the recovery of world trade until 2011. However, the reshoring phenomenon resumed from 2011 to 2014, and it is forecast that this situation will remain unchanged in the near future (Timmer et al., 2016). From this, we can surmise that the determining causes resided in a series of factors that went beyond the context of the economic crisis and the decline in global demand.

Although this phenomenon is very recent, there is already sufficient empirical evidence that analyses the determinants of the reshoring processes in manufacturing for material inputs Fratocchi et al., 2014, Martínez-Mora and Merino, 2014; Tate, 2014, Tate et al., 2014; Bailey and De Propris, 2014; Dachs and Zanker, 2015; Arlbjørn and Mikkelsen, 2015; Stentoft et al., 2016; Vecchi, 2017; Johanson and Olhager, 2018 y Di Mauro et al., 2018). However, the available empirical evidence consists in case studies, given the scarce availability of data for the global analysis of the process. There is only one very recent study that examines the determinant factors of reshoring through a large-scale analysis of manufacturing companies which, using a probit estimate, studies the probability of whether a reshoring process will be carried out or not depending on the variables considered in the model (Delis et al., 2019).

However, the reshoring of services has hardly been analysed. There are only two studies (Albertoni et al., 2015, 2017) in which the determinant causes of this process in services are studied for the first time. The first is a descriptive analysis and the second a logistic estimate in which the dependent variable is reshoring.

Both the offshoring and the more recent reshoring phenomena have been widely reported by the media due to the supposed implications for employment. Public opinion and certain political leaders, such as Donald Trump in the USA, associate offshoring with job losses in advanced countries in favour of gains in emerging nations, and, on the contrary, 
they contemplate reshoring strategies as a possibility to generate employment in the developed world. This premise underlies the recent tightening of the USA's trade policy, which will predictably have a response from the EU, as set out in the draft of the EU Strategic Agenda for 2019-2024. One of the points of this Agenda calls for a more ambitious trade policy in reciprocation for the countries that obstruct its markets.

It has been widely demonstrated ${ }^{1}$ that the impact of the offshoring strategy on reducing employment is in some cases null and in others very small. This is also the case in Spain (Fuster et al. 2019). However, it has also been shown that the strategy is competitive, as it improves the profitability of the companies and their exports (Martínez-Mora and Merino, 2017, 2019; Fuster and Martínez-Mora, 2012; Gandoy et al., 2018; Díaz-Mora et al. 2018; Chiappini, 2012; Bogliacino, 2018; Moser, 2015; Wagner, 2011). In other words, the empirical evidence of the effects of offshoring processes confirms the theoretical predictions, showing that it is a competitive strategy, as it improves the results of companies and should therefore have positive effects on employment, or at least there should be no negative effects.

But in the case of reshoring, there are still no studies, either for the manufacturing or services sectors that analyse its effects on employment or the competitiveness of companies.

This study addresses these aspects relating to the effects of the reshoring processes on the level of employment for the first time in the economic literature. First, we will measure the size of the phenomenon of reshoring services in Spain and second, we will analyse its impact on the generation of employment. The study only focuses on backshoring situations, consisting in the return to the home country of activities that had been previously offshored (Albertoni et al., 2017; Delis et al., 2019), which are those that hypothetically could have some impact on the generation of employment.

The study is structured as follows. After the introduction, Section 2 refers to the scarcity of available previous empirical evidence on the recent reshoring phenomenon. Section 3 describes the methodology used for the analysis and measurement of the reshoring (backshoring) of services in Spain through sectoral data, and the results are presented in Section 4. Section 5 addresses the study of its impact on employment. This section refers, first, to the non-existence of previous empirical evidence regarding the analysis of this

\footnotetext{
${ }^{1}$ In Hummels et al. (2018) there is a detailed description of the available empirical evidence.
} 
impact or an underlying theoretical framework and, second, it explains the methodology that will be used to estimate it and then presents the results. Finally, section 6 describes the conclusions of the study.

\section{Previous evidence}

The economic analysis of the reshoring phenomenon still requires further development with new contributions that will enable us to gain a more in-depth understanding of this strategy, particularly its determining causes and its effects.

Reshoring is a strategy that has emerged so recently that there has hardly been enough time for it to be analysed in the academic literature, although it is one of the most active topics among the research fields of International Business, given the speed with which the empirical studies on this issue are being published.

The existing empirical evidence on reshoring is focused on analysing its determining causes, based on the traditional theoretical framework normally used in the offshoring literature (Kinkel et al., 2007; Mudami and Venzin, 2010; Orberg and Pedersen, 2011; Mclvor, 2013), that is, internationalisation theory, the eclectic paradigm and transaction cost theory (Rugman, 1981; Dunning, 1980a, 1980b, 1993, 2000; Contractor et al, 2010; Buckley and Casson, 1976; Ellram et al., 2008).

However, it should be noted that the literature on offshoring contains more recent additional theoretical developments that explain its underpinnings and effects. One of these developments is the global value chain approach (GVC) which, among other aspects, provides the methodology to measure the degree of vertical specialisation that is generated in international trade when the production processes are carried out in different stages located in different countries, that is, when offshoring processes are developed. Within the theoretical framework of GVCs, Koopman et al. (2014) propose an accounting framework of the added value that is generated in each country where each of the stages of the production processes is located. This methodology has been used in many empirical studies (Pahl et al., 2019; Díaz-Mora et al., 2018; Solaz, 2018; Dell'Agostino and Nenci, 2018).

Other developments found in the International Business literature include studies that analyse the growing globalisation of innovation and the role that multinational companies have played in promoting this phenomenon through their offshoring processes. Initially, 
in the 1980s and 1990s, the offshoring processes of the multinational companies from Europe, Japan and the United States only consisted in the transfer of the results of their innovations to their affiliates in the emerging countries so that they could be exploited by their local markets, but the generation of innovation remained within the advanced economies (Lall, 1993; Pavitt and Patel, 1999). However, this trend has been changing in recent years, due to the fact that in the developing countries in which the multinational firms implement their offshoring processes, the availability of highly qualified labour has grown considerably and still at a low cost (Ernst, 2005; Lewin et al., 2009). This has led to global changes in the geography of the generation of innovation, which is no longer concentrated in the advanced economies and is growing in emerging economies, such as Brazil, India or China (Lema, 2015; Chaminade and Barnard, 2012). There is abundant empirical evidence on offshoring which analyses these processes (Chesbrough, 2006; Cooke, 2005; Simard and West, 2006; Ariffin, 2000; Ariffin and Figueiredo, 2006; CanoKollman et al. 2016).

The growing globalisation of innovation is generating structural reorganisations in the supply sources of the multinational companies in their offshoring processes (Petricevic and Teece, 2019). It has also led to a reconsideration of the traditional theories included in Dunning's eclectic paradigm (Dunning 1980a, 1980b, 1993, 2000) on the reasons for the international expansion of multinational firms, in order to identify the new reasons that are driving it (Cuervo-Cazurra and Narula, 2015). One of these reasons is based on management quality (Bloom et al., 2009). Serrano and Myro (2019) show that those multinational companies that undertake foreign direct investment processes or decentralise their supply sources in international markets through offshoring processes are more productive and better managed.

With respect to the literature on reshoring, there are many case studies, previously cited, of different manufacturing sectors and different countries, that identify common causes in all of them which can be summarised in two facts. On the one hand, a major cause was the onset of the global financial crisis of 2008-2013 which modified the factors that had motivated the strategic offshoring decision in the past. We are basically referring to the reduction of the wage differences between advanced countries and the countries in southeast Asia, due to the increase in the latter and the reduction in the former, caused by the high unemployment rates generated in the developed world due to the crisis (Shih, 2013). In manufacturing, a large part of the relocation of the production of inputs was transferred 
from the developed countries to Asian countries. On the other hand, other causes are derived from the emergence of hidden costs initially unforeseen in the offshoring decision and which have led to the partial or total reversal of this strategy.

An interesting study has been published very recently with company data (Delis et al., 2019), offering a large-scale analysis of the factors that influence a firm's decision to reshore. The period of study is 2006-2013 and it is based on a sample of 3683 multinational companies (MNCs) in the manufacturing sector of fourteen OECD countries with affiliates in less developed countries. The econometric estimation is based on a binomial probit model, which incorporates two levels of variables, the characteristics of the companies and the home and foreign countries.

The study comprehensively reveals the relevant causes of the phenomenon. With respect to the characteristics of the companies it finds that the reshoring operations increase when the ratio of the wage rates paid in subsidiaries to those paid in parent companies increases and when the flexibility to reverse the operations with subsidiaries is higher. They decrease when the turnover of the subsidiaries improves and when the relative capital between subsidiaries and parent companies increases. With respect to the other variables, the results obtained show that the reshoring processes are evident mostly from the beginning of the crisis for European MNCs. Past experience in reshoring processes facilitates the repetition of the strategy in subsequent periods. Finally, the greater the distance between the country of origin and the destination, the lesser the effect of the wage differences.

For the reshoring of services, the empirical evidence is much scarcer. There is only one study (Albertoni et al., 2015) that describes the phenomenon and another subsequent study (Albertoni et al., 2017), in which the determinants are estimated with company data. This study is based on the database developed by the Offshoring Research Network (ORN), which contains 5000 observations with information on the intentions of companies to undertake reshoring. Of these, the sample used in the regression analysis comprises 454 observations, with a percentage of reshoring operations of $10 \%$ of the sample. The process of relocating the service activities for companies in the manufacturing and service industries is analysed for the period 2005-2011.

Based on a logistic estimate in which the dependent variable, reshoring, is a dummy variable, this study analyses the propensity to reshore depending on the control variables 
selected in the model. The results reveal that the inclination to take the reshoring decision is higher, first, when there is a higher possibility of a disintegration of the activities in the value chain, as this will facilitate their integration back into the company in the home country. And second, when the factors that motivated the previous offshoring strategy, such as the access to new markets, the search for efficiency or cost reduction, are modified, obstructing the achievement of the original objectives of the offshoring operation.

\section{Methodology}

In the empirical literature, the offshoring indexes obtained through input-output tables have been calculated in two alternative ways. Following the methodology initially proposed (Feenstra \& Hanson, 1996, 1999), offshoring is measured as the proportion of imported inputs (II) relative to the total inputs used, both domestic and imported (TI). However, more recently, offshoring is also being measured as the proportion of imported inputs (II) relative to the value of production (Y), the latter being the most frequently used indicator in the literature (Campa and Goldberg, 1997; Díaz Mora et al., 2007; Cadarso, et al., 2008, 2012; Michel and Rycx, 2012; Castellani et al., 2013; Fuster et al, 2019).

$$
O 1_{j t=} \frac{\sum_{i=1}^{n} I I_{i j t}}{Y_{j t}} \quad \text { (1) } \quad 02_{j t=} \frac{\sum_{i=1}^{n} I I_{i j t}}{\sum_{i=1}^{n} T I_{i j t}}
$$

O1jt and $\mathrm{O} 2 \mathrm{jt}$ are the two alternative indexes used to measure the level of offshoring of sector $\mathrm{j}$ in year $\mathrm{t}$. IIijt represents the inputs of sector $\mathrm{i}$ imported by sector $\mathrm{j}$ in year $\mathrm{t}$. Yjt refers to the value of the production of sector $\mathrm{j}$ in year $\mathrm{t}$. And, finally, TIijt represents total inputs (national and imported) of sector $\mathrm{i}$ used by sector $\mathrm{j}$ in year $\mathrm{t}$.

An increase (decrease) in the index defined with any of the two previously-defined indicators (II/Y and II/TI) reflects a greater (lesser) dependence on imported inputs. In the first case, by unit of production and, in the second case, with respect to total intermediate consumption (domestic and imported).

In both cases, an increase in the offshoring index could be the result of the replacement of domestic suppliers with foreign suppliers or a process of international fragmentation of production, i.e. the substitution of company production with imported inputs. 
Meanwhile, a decrease in the offshoring index, namely reshoring, could be derived from a replacement of foreign suppliers with domestic suppliers or internal production.

In order to analyse whether an increase (decrease) in the proportion of imported inputs is caused by a change in the source of supply or in internal production, we can break down the offshoring indicator, defined as the proportion of imported inputs relative to the value of production (II/Y), into two components. On the one hand, the proportion that imported inputs represent of total inputs used, both domestic and imported, (II/TI) and, on the other hand, the total inputs used in relation to the value of production (TI/Y).

$\frac{I I}{Y}=\frac{I I}{T I} X \frac{T I}{Y}$

$\frac{\sum_{i=1}^{n} I_{i j t}}{Y_{j t}}=\frac{\sum_{i=1}^{n} I I_{i j t}}{\sum_{i=1}^{n} T_{i j t}} X \frac{\sum_{i=1}^{n} T_{i j t}}{Y_{j t}}$

When there is an increase in the first ratio of equation (3), (II/Y), that is, when the imported inputs per unit of product increase, we say that there is offshoring. If this increase is accompanied by an increase in the other two ratios, this indicates an increase in the proportion of total inputs in relation to the value of production (increase in TI/Y), which means that some inputs that were previously produced internally are now being externalised and substituted by foreign suppliers (increase in II/TI). This situation is called international fragmentation of production. However, if the increase in the first ratio (II/Y) is accompanied by a negative or no variation in the third ratio (TI/Y), this would mean that the proportion of total inputs per unit of production reduces or remains the same, which would indicate that the use of national inputs from domestic suppliers is reduced and replaced by foreign suppliers.

In the same way, we can study whether a decrease in the offshoring index (reshoring) is the result of the replacement of foreign suppliers by domestic suppliers or by internal production.

This decomposition of the offshoring index has been used to analyse the offshoring of materials in the Spanish economy (Díaz Mora et al., 2007), to study the offshoring of both materials and services in Italy (Castellani et al., 2013) and to study the offshoring of 
services in Spain between 2000 and 2007 (Fuster and Martínez-Mora, 2013). This study uses this breakdown to analyse the reshoring that began to take place with the onset of the crisis in 2008.

\section{Entity of reshoring of services in Spain}

The empirical study reveals a growing evolution in the service offshoring strategy in Spain between 2000 and 2008 and a change in trend from the beginning of the economic crisis, highlighting the existence of a process of reshoring of services from 2008. The reduction in the offshoring index, defined as the proportion of imported inputs of services with respect to production, in the early years of the crisis was so large that in 2010 the Spanish economy reported service offshoring indexes lower than those of the year 2000. While in the period 2000-2008 the practice of offshoring of services grew at an average annual rate of $3.38 \%$ for the whole of the Spanish economy, in the years 2008-2010 this practice reduced noticeably to an average annual rate of $-22.16 \%$.

The analysis of the service offshoring index for the manufacturing and service sectors reveals the existence of reshoring in both sectors since 2008. While the strategy of service offshoring was more intense in the services branches than in manufacturing during the growth period between 2000 and 2007, the lower dependency on imported intermediate services observed from the beginning of the recent crisis (reshoring) has been more prominent in manufacturing (Graph 1, Graph 2).

Graph 1. Imported intermediate services over the value of production (II/Y) (in percentages) 


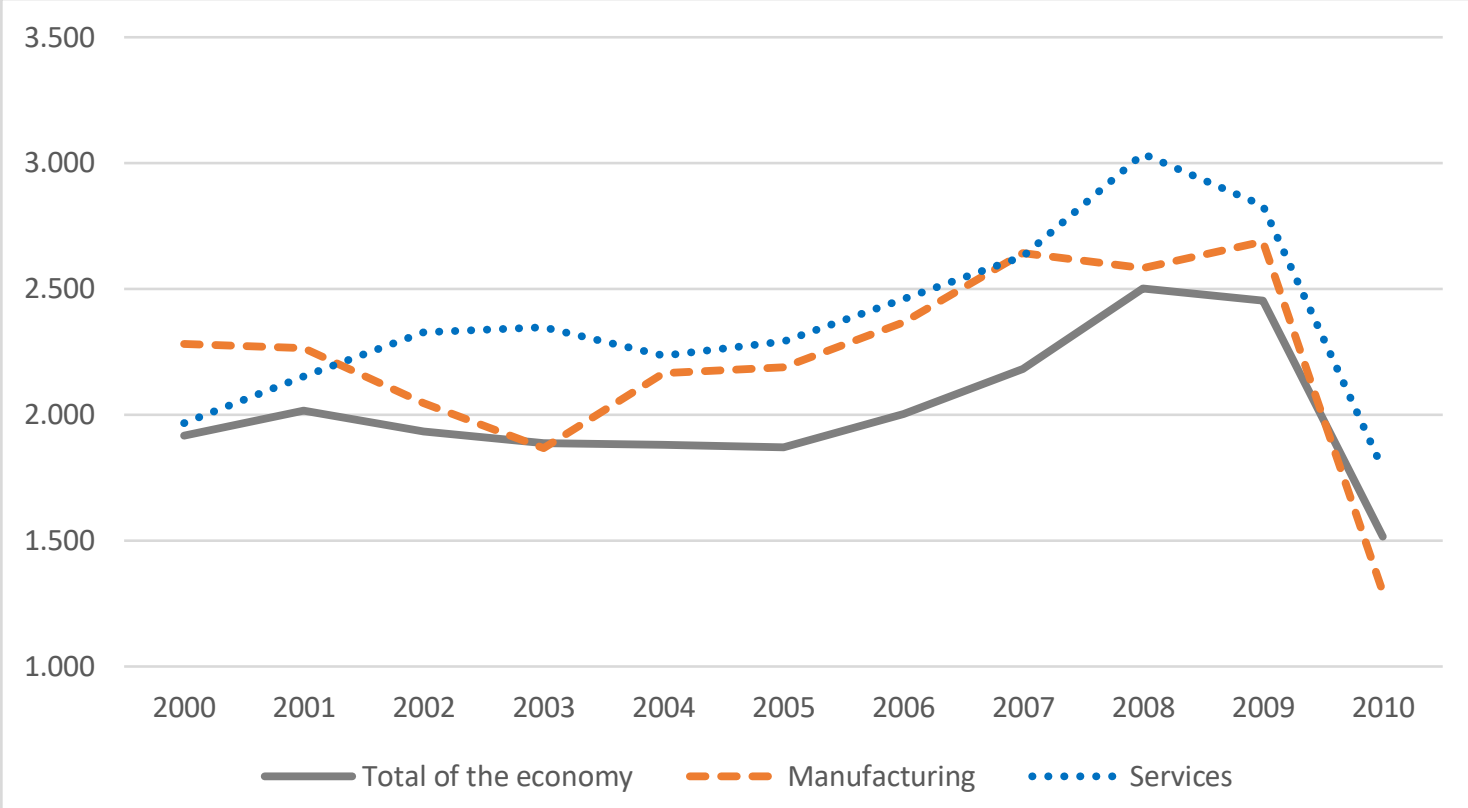

Source: Own elaboration based on the Input-Output Tables of Spain's National Accounts, INE

However, the data available for 2015 reveal an increase in the dependency on imported intermediate services between 2010 and 2015 which was much more intense in the services sector $(4.25 \%)$ than in the manufacturing sector $(0.63 \%)^{2}$. These data indicate that the phenomenon of the reshoring of services detected between 2008 and 2010 is a reflection of the great trade collapse that followed the international financial crisis in the years 2008 and 2009 (Baldwin and Taglioni, 2009), given that, once world trade had recovered, an increase in the dependency on foreign services may be observed again, although it was much less intense than during the period prior to the crisis (Graph 2). It is well known that, after the collapse, global trade recovered, but not at the same pace as world GDP and a deceleration may be observed from 2011, which could be due to the possible decline of the global value chains, which implies a substitution of imports with national goods (Timmer et al., 2016).

We can confirm that a relevant services reshoring process took place after the international financial crisis, which was more intense in manufacturing and its effects persisted in the following years. Although a new growth trend may be observed in the content of imported intermediate services between 2010 and 2015, the level reached in

2 Input-Output tables of the Spanish National Accounts published by the Spanish Statistics National Institute (INE by its initials in Spanish) from 2010 include the import destination table every five years, in other words, the next year in which they are completed is 2015. As this information for the years between 2011 and 2014 is not available, the analysis for these years cannot be carried out. Hence, the calculations have been made for the period 2000-2010 and for the year 2015, the last available year with complete information. 
2015 continued to be much lower than that recorded in 2008 (Graph 3). This new change in trend is practically insignificant in manufacturing and very small in services. In fact, in 2015 a high percentage of activities that had returned since 2008 remained in the home country and were not offshored again.

Graph 2. Imported intermediate services over the value of production (II/Y) (annual average rate of change)

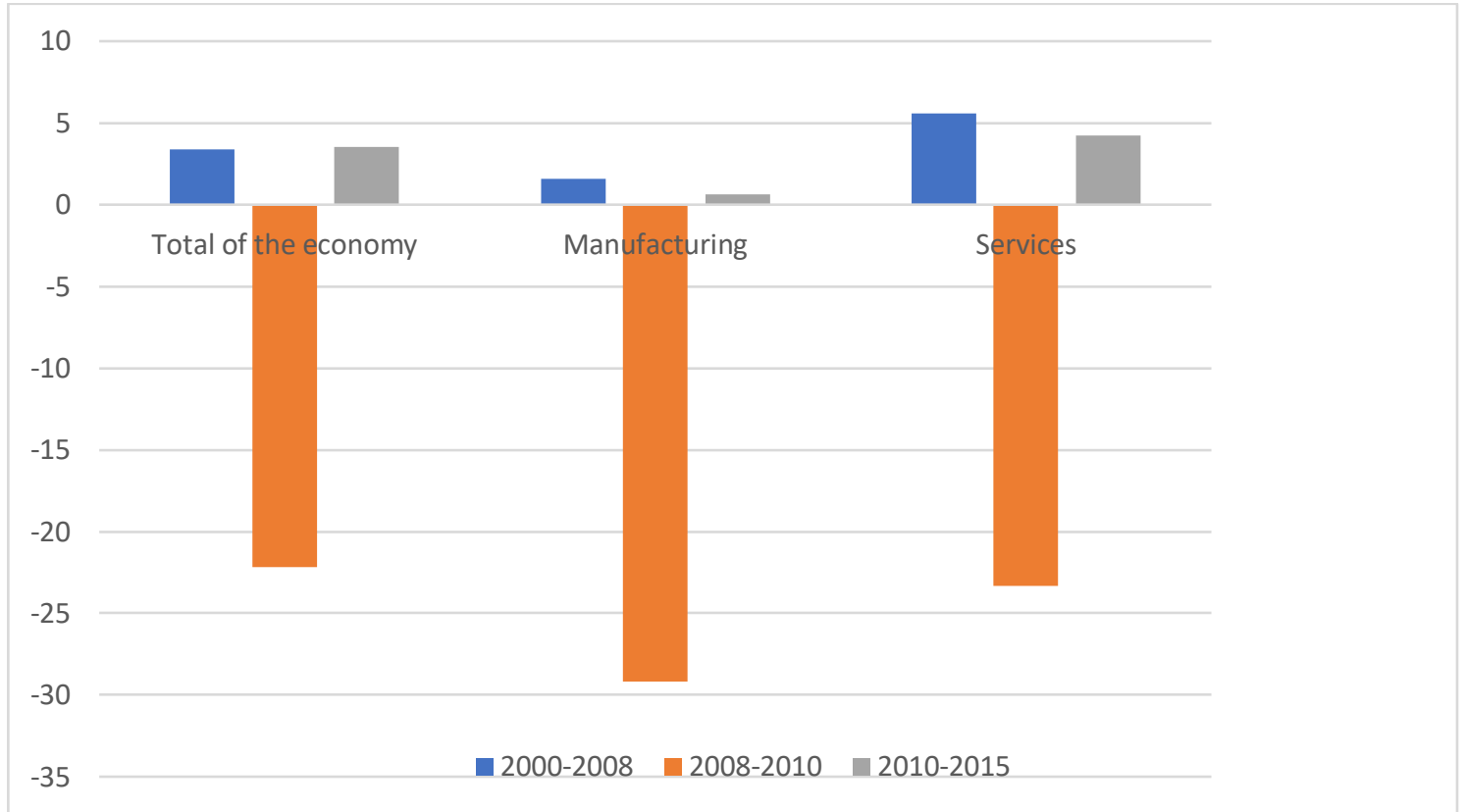

Source: Own elaboration based on the Input-Output Tables of Spain's National Accounts, INE.

Graph 3. Imported intermediate services over the value of production (II/Y) (in percentages)

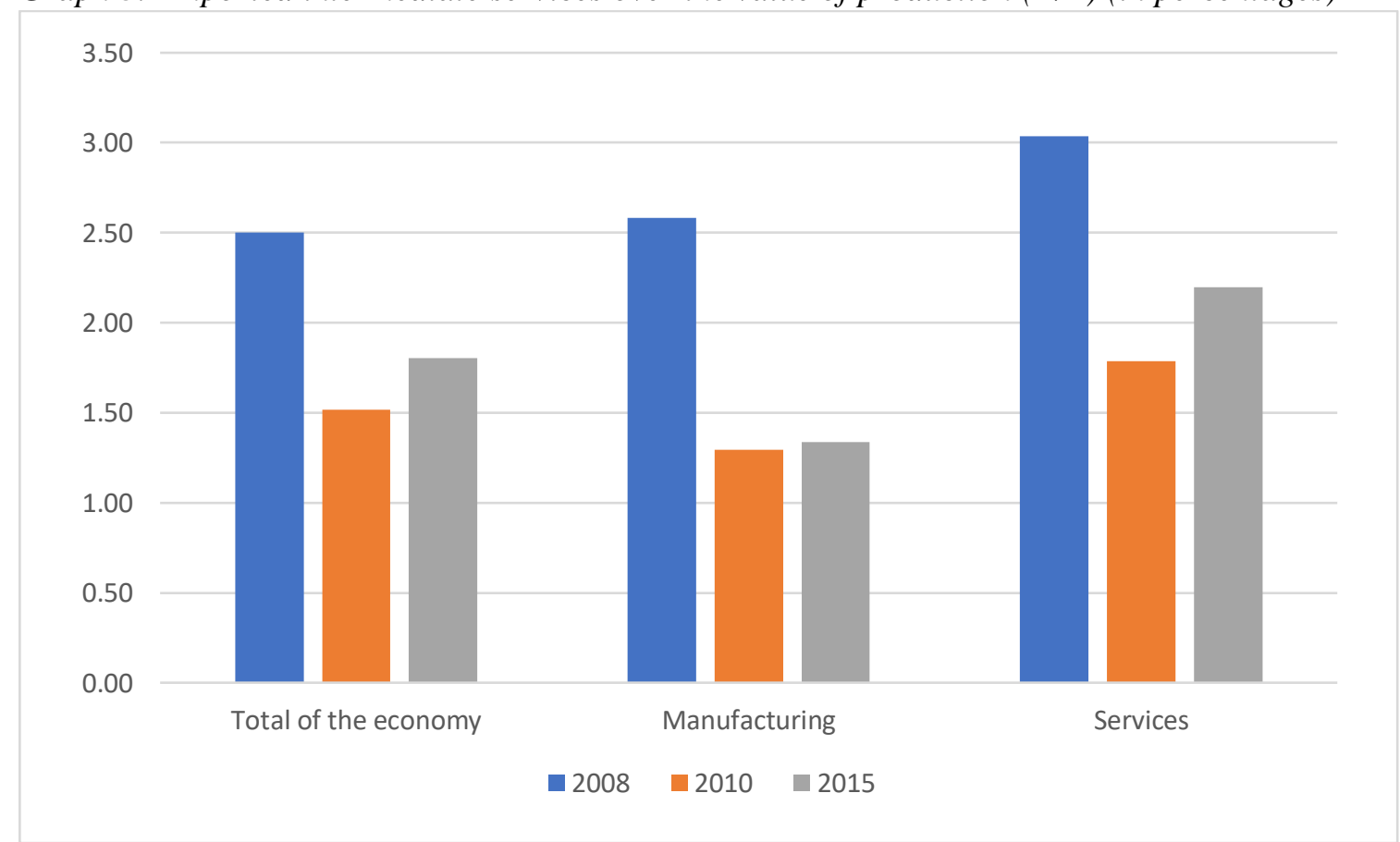

Source: Own elaboration based on the Input-Output Tables of Spain's National Accounts, INE. 
Given that a process of reshoring services was detected in the Spanish economy during the early years of the economic crisis, we will focus on the description of the characteristics of this process between the years 2008 and 2010.

The indicator of imported intermediate services in relation to total intermediate services (II/TI) decreased for the economy as a whole from 2008 to 2010 at an average annual rate of $-23.80 \%$, with the same trend being recorded for the manufacturing and service sectors (Graph 4). This result indicates that in Spain during this period the contracting of imported intermediate services decreased in both manufacturing and services with respect to the total intermediate services used, within the context of the collapse of world trade caused by the international financial crisis (Baldwin and Taglioni, 2009). Although the manufacturing sector imports a higher proportion of the intermediate services used in comparison with services, the weight of the foreign component has reduced more quickly than in services $(-27.71 \%$ and $-23.86 \%$ respectively). This reduction in imports could have been replaced by contracting inputs from domestic suppliers or internalising them in the companies.

Graph 4. Imported Intermediate services over total intermediate services (II/TI) (in percentages)

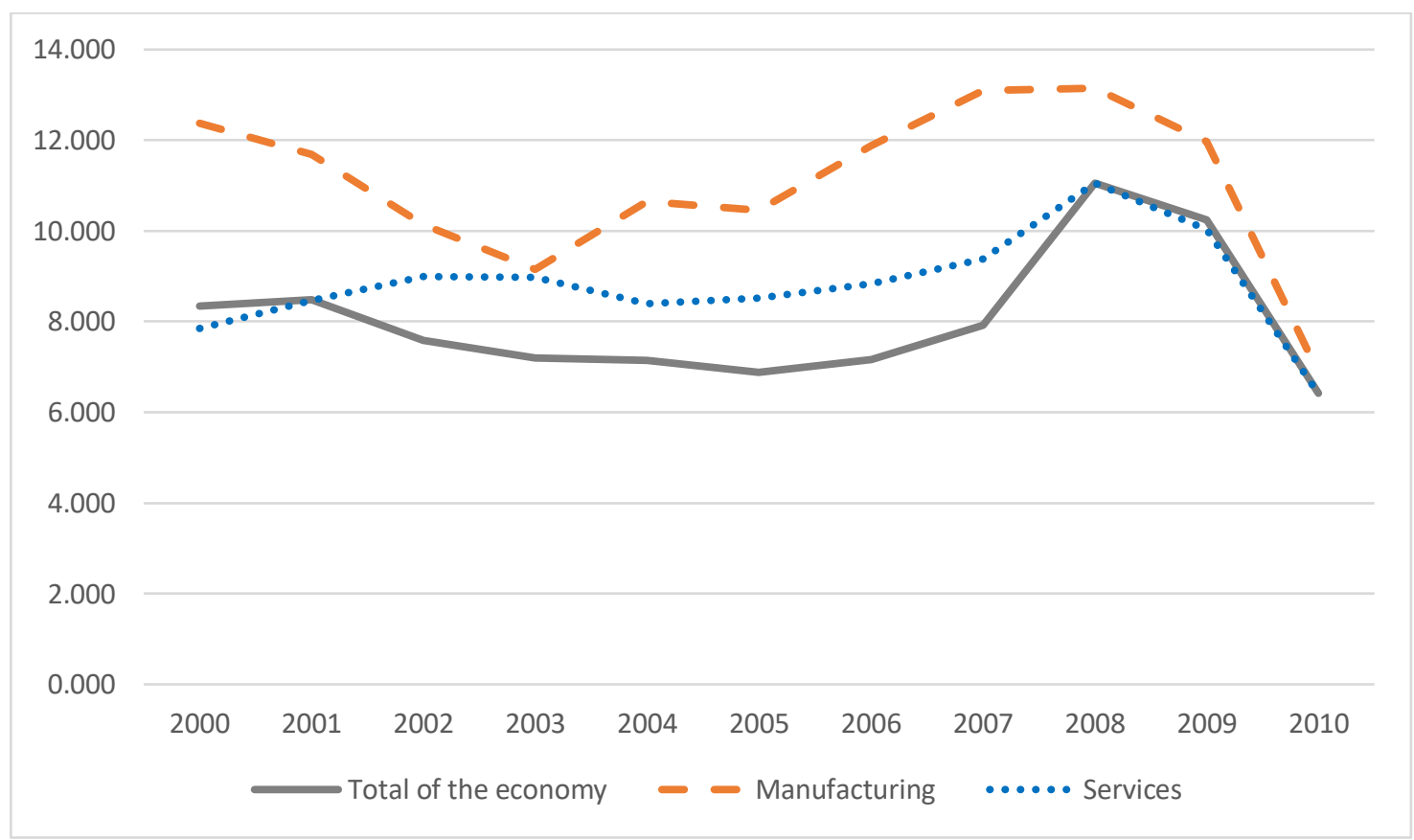

Source: Own elaboration based on the Input-Output Tables of Spain's National Accounts, INE:

The analysis of the index of total intermediate services used in the economy with respect to the value of production (TI/Y) reveals that between 2008 and 2010 the reduction in 
imported services inputs was replaced by the internal production of these services by the manufacturing sectors, while in the service industries imports were replaced by domestic external suppliers (Table 1).

Table 1: Reshoring of services 2008-2010

\begin{tabular}{|c|c|c|c|c|}
\hline & 2008 & 2009 & 2010 & $\begin{array}{l}\text { Annual average rate of change } \\
2008-2010\end{array}$ \\
\hline \multicolumn{5}{|c|}{ Inputs of imported services/production (\%) } \\
\hline Total of the economy & 2.502 & 2.455 & 1.516 & -22.16 \\
\hline Manufacturing & 2.583 & 2.688 & 1.296 & -29.17 \\
\hline Services & 3.037 & 2.831 & 1.785 & -23.33 \\
\hline \multicolumn{5}{|c|}{ Inputs of imported services/total inputs of services (domestic + imported) (\%) } \\
\hline Total of the economy & 11.054 & 10.238 & 6.419 & -23.80 \\
\hline Manufacturing & 13.148 & 11.969 & 6.871 & -27.71 \\
\hline Services & 11.054 & 10.037 & 6.408 & -23.86 \\
\hline \multicolumn{5}{|c|}{ Total inputs of services (domestic + imported)/value of production } \\
\hline Total of the economy & 0.226 & 0.240 & 0.236 & 2.11 \\
\hline Manufacturing & 0.196 & 0.225 & 0.189 & -1.92 \\
\hline Services & 0.275 & 0.282 & 0.279 & 0.78 \\
\hline
\end{tabular}

Source: Own elaboration based on the Input-Output Tables of Spain's National Accounts, INE.

The sectoral analysis is presented below, first for the manufacturing branches and then for the services branches.

Based on the High-tech classification of manufacturing industries of Eurostat (2018), the manufacturing branches have been classified into three groups according to their technological intensity: High-technology (includes high-technology and medium hightechnology industries); Medium-technology (includes medium low-technology industries); and Low-technology (includes low-technology industries). This analysis reveals that the importance of the reshoring of services between 2008 and 2010 differed depending on the technological content of the manufacturing branches, whereby the lower the technological content of the manufacturing branch the higher the incidence of reshoring. The manufacturing branches with a low technological content are those that most reduced the dependency on imported intermediate services in the period 2008-2010, with the exception of wood and cork (Graph 5). A probable explanation is that in the period of economic growth, the quota of foreign services with respect to production grew more quickly and reached higher levels in this group of industries compared with the rest. This may be due to the fragmentation and geographical dispersion of the production of low technology industries that require extensive transport, logistics and other supply 
chain management services, which are sourced externally by most manufacturers (Nordås and Kim, 2013). With the onset of the crisis, these industries adopted the opposite strategy, reversing the initial offshoring strategy. At the other extreme, we can observe a lower incidence of reshoring by more technology intensive industries, as they are those that least reduce the content of imported intermediate services per unit of product, with the exception of the manufacture of electrical equipment and chemical products. This result can be linked to the high involvement of industries with a high technological content in the global value chains (Gandoy et al., 2018).

Graph 5: Reshoring of services in branches of manufacturing in accordance with technological intensity, 2008-2010 (rate of change of the index II/Y)

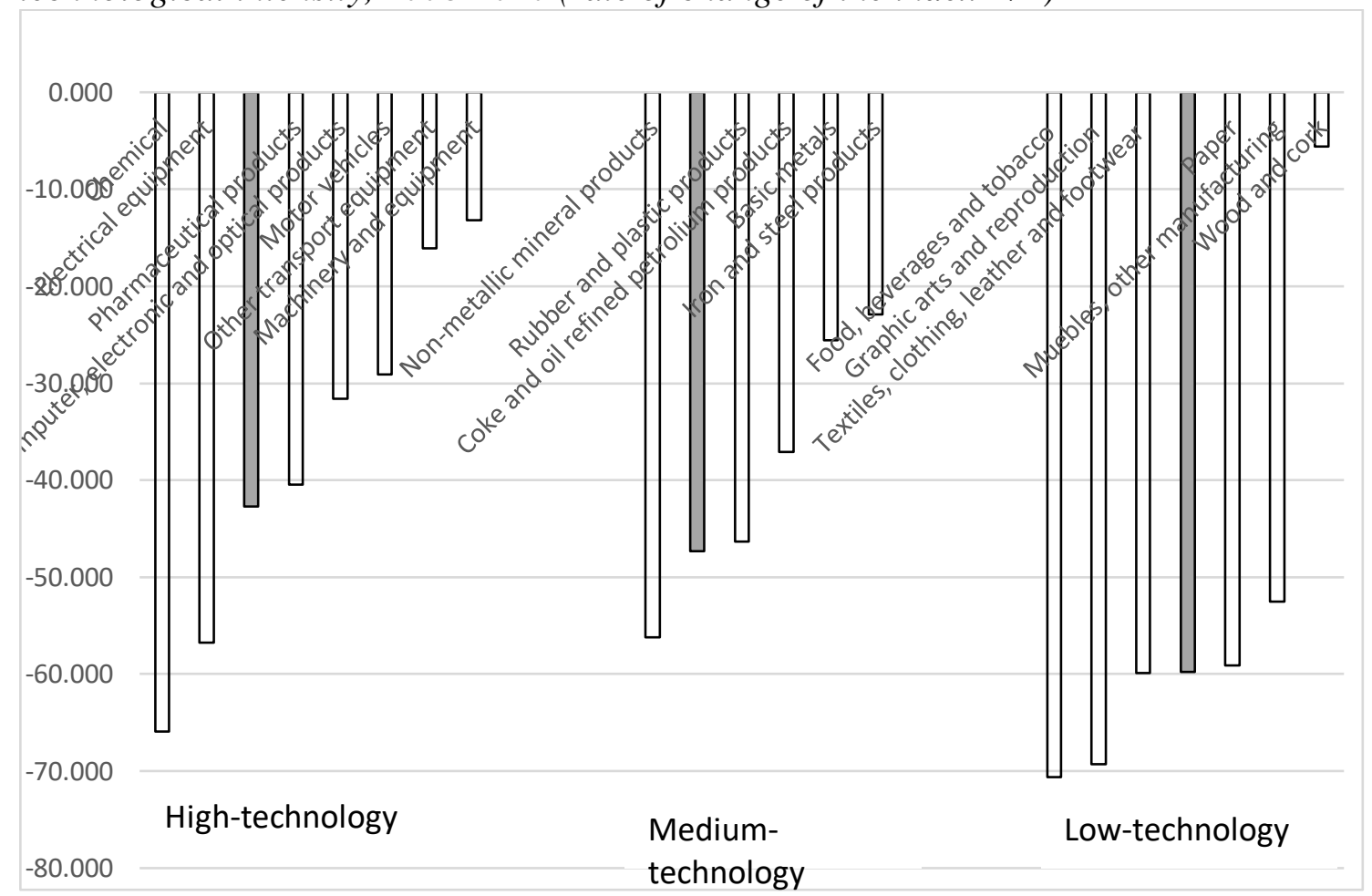

Note: The dark shaded column represents the average rate of change of the reshoring of services of each manufacturing group. Source: Own elaboration based on the Input-Output Tables of Spain's National Accounts, INE.

The reshoring of services strategy observed in all of the manufacturing branches has implied the substitution of foreign intermediate services with internal production in the majority of the branches (Table 2).

Table 2. Reshoring of services in manufacturing, 2008-2010

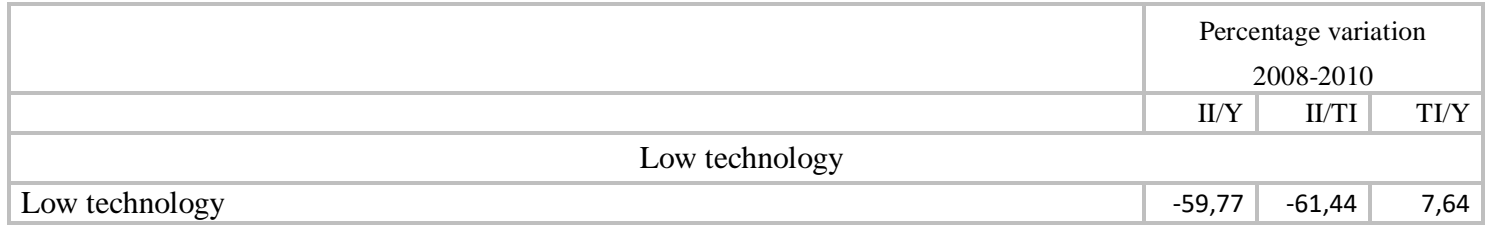




\begin{tabular}{|c|c|c|c|}
\hline Food, beverages and tobacco & -70.60 & -64.68 & -16.97 \\
\hline Textiles, clothing, leather and footwear & -59.92 & -60.02 & 0.12 \\
\hline Wood and cork, except furniture; basketry and esparto & -5.58 & -25.30 & 26.46 \\
\hline Paper & -59.12 & -51.41 & -16.04 \\
\hline Graphic arts and reproduction of recorded media & -69.28 & -74.75 & 21.68 \\
\hline Furniture, other manufacturing industries & -52.55 & -62.17 & 25.37 \\
\hline \multicolumn{4}{|c|}{ Medium technology } \\
\hline Medium technology & $-47,32$ & $-38,63$ & $-4,85$ \\
\hline Coke and oil refined petroleum products & -22.90 & -27.27 & 6.66 \\
\hline Rubber and plastic products & -46.37 & -48.05 & 3.53 \\
\hline Non-metallic mineral products & -25.61 & -27.69 & 2.94 \\
\hline Iron, steel and ferroalloy products & -56.23 & -41.17 & -25.63 \\
\hline Basic metals & -37.06 & -42.83 & 10.10 \\
\hline \multicolumn{4}{|c|}{ High technology } \\
\hline High technology & $-42,71$ & $-38,34$ & $-2,14$ \\
\hline Chemical & -56.74 & -52.89 & -8.01 \\
\hline Pharmaceutical products & -31.62 & -23.43 & -10.58 \\
\hline IT, electronic and optical products & -65.92 & -61.12 & -12.22 \\
\hline Electrical material & -40.42 & -42.96 & 4.36 \\
\hline Machinery and equipment & -16.09 & -23.78 & 10.23 \\
\hline Motor vehicles & -13.21 & -4.57 & -9.07 \\
\hline Other transport equipment & -29.12 & -40.87 & 20.14 \\
\hline
\end{tabular}

Source: Own elaboration based on the Input-Output Tables of Spain's National Accounts, INE:

The service sector also recorded reshoring between 2008 and 2010, although with less intensity than the manufacturing sector. Furthermore, different behaviours can be observed in the different branches of services. Given the high level of heterogeneity within services, the service activities have been classified according to their knowledge intensity, based on the Knowledge-intensive services (KIS) classification of Eurostat (2016), in order to analyse the differences observed between different groups. The different services branches have been grouped into five categories: High-tech knowledgeintensive services (HKIS), Knowledge-intensive market services -excluding financial intermediation and high-tech services- (MKIS), Knowledge-intensive financial services (FKIS), Other knowledge-intensive services (OKIS) and Low Knowledge-intensive services (LKIS). The last group comprises the services that are not included in the other four groups defined by Eurostat (2016).

The results show that the Knowledge-intensive financial services (FKIS) recorded the highest level of reshoring in the period 2008-2010. In other words, there was a greater fall in the content of foreign intermediate services with respect to their production. This group includes: Financial service activities, Insurance, reinsurance and pension funding and Activities auxiliary to financial services and insurance activities, all of which implemented strategies of reshoring services between 2008 and 2010. At the other end of the scale is the group that has least reduced its dependency on imported intermediate 
services; High-tech knowledge-intensive services (HKIS). All of the activities making up this group (Computer programming and consultancy, $\mathrm{R}+\mathrm{D}$, Telecommunications and Motion picture, video and television programme production), together with those of FKIS, have practised reshoring of services, although with a lower intensity. The remaining groups (MKIS, LKIS and OKIS, ordered from least to greatest incidence of reshoring) include highly heterogeneous activities with respect to this type of strategy, as they include both activities whose dependence on services sourced from other countries has diminished (reshoring) and others in which it has increased (offshoring) (Graph 6). Therefore, contrary to what we can observe in manufacturing, not all of the services branches have recorded reshoring strategies. This is the case of Water transport, Advertising and market research and Employment activities, within the MKIS group; Rental and leasing activities, Activities of membership organisations, Accommodation services; food and beverage services and Land transport, in the LKIS group; and Public administration and defence, Social services activities, Human health activities and Education, in the OKIS group.

Graph 6: Reshoring of services in branches of services according to technology knowledge, 2008-2010 (rate of change of the II/Y index)

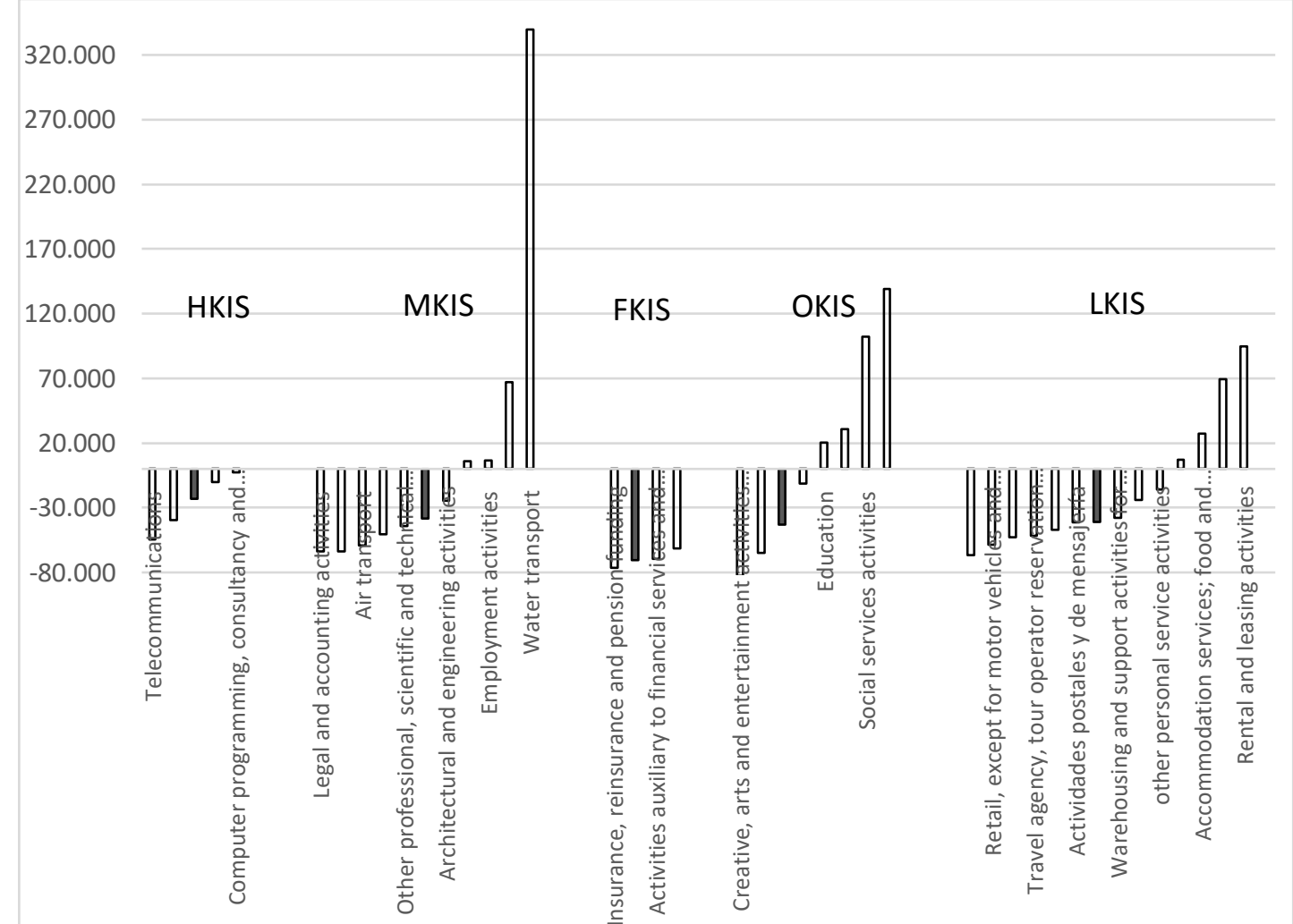

Note: High-tech knowledge-intensive services (HKIS), Knowledge-intensive market services -excluding financial intermediation and high-tech services- (MKIS), Knowledge-intensive financial services (FKIS), Other knowledge-intensive services (OKIS) and Low Knowledge-intensive services (LKIS).

The dark shaded column represents the average rate of change of reshoring of services of each services group. Source: Own elaboration based on the Input-Output Tables of Spain's National Accounts, INE. 
In the branches of services that practice reshoring, this strategy has involved a change from foreign to national suppliers in the majority of cases, although we can also observe that in some activities the import of inputs is replaced by internal production (Table 3).

Table 3. Offshoring and Reshoring of services in services, 2008-2010

\begin{tabular}{|c|c|c|c|}
\hline & \multicolumn{3}{|c|}{$\begin{array}{l}\text { Percentage variation } \\
\quad 2008-2010\end{array}$} \\
\hline & $\mathrm{II} / \mathrm{Y}$ & II/TI & $\mathrm{TI} / \mathrm{Y}$ \\
\hline \multicolumn{4}{|l|}{ High-tech knowledge-intensive services (HKIS) } \\
\hline Telecommunications & -54.50 & -55.71 & 2.74 \\
\hline $\begin{array}{l}\text { Motion picture, video and television programme production, sound recording and music } \\
\text { publishing activities }\end{array}$ & -39.45 & -40.80 & 2.27 \\
\hline Scientific research and development & -10.01 & 1.00 & -11.01 \\
\hline Computer programming, consultancy and related activities & -2.44 & 11.66 & -12.70 \\
\hline \multicolumn{4}{|c|}{ Knowledge-intensive market services -excluding financial intermediation and high-tech services- (MKIS) } \\
\hline Legal and accounting activities & -63.89 & -66.18 & 6.61 \\
\hline Security and investigation activities & -63.83 & -66.08 & 6.72 \\
\hline Air transport & -59.21 & -65.18 & 17.14 \\
\hline Repair of computers and personal and household goods & -50.62 & -55.30 & 10.63 \\
\hline Other professional, scientific and technical activities & -44.39 & -39.07 & -8.59 \\
\hline Architectural and engineering activities & -24.78 & -28.92 & 5.74 \\
\hline Repair and installation of machinery and equipment & 5.79 & -13.57 & 22.47 \\
\hline Employment activities & 6.58 & -6.83 & 14.21 \\
\hline Advertising and market research & 67.07 & 68.34 & -0.69 \\
\hline Water transport & 339.75 & 259.44 & 22.32 \\
\hline \multicolumn{4}{|l|}{ Knowledge-intensive financial services (FKIS) } \\
\hline Insurance, reinsurance and pension funding, except compulsory social security & -76.31 & -74.74 & -6.28 \\
\hline Activities auxiliary to financial services and insurance activities & -69.50 & -68.52 & -3.14 \\
\hline Financial service activities, except insurance and pension funding & -61.26 & -69.99 & 29.16 \\
\hline \multicolumn{4}{|l|}{ Other knowledge-intensive services (OKIS) } \\
\hline $\begin{array}{l}\text { Creative, arts and entertainment activities ; Libraries, archives, museums and other cultural } \\
\text { activities; Gambling and betting activities }\end{array}$ & -82.61 & -80.87 & -9.21 \\
\hline Sports activities and amusement and recreation activities & -64.92 & -65.28 & 1.03 \\
\hline Publishing activities & -11.34 & -16.94 & 6.76 \\
\hline Education & 20.14 & 0.54 & 19.68 \\
\hline Human health activities & 30.63 & 28.83 & 1.56 \\
\hline Social services activities & 102.35 & 158.07 & -21.50 \\
\hline Public administration and defence; compulsory social security & 138.95 & 171.38 & -11.93 \\
\hline \multicolumn{4}{|l|}{ Low Knowledge-intensive services (LKIS) } \\
\hline Maritime transport and inland shipping & -66.41 & -68.05 & 5.19 \\
\hline Retail, except for motor vehicles and motorcycles & -58.47 & -64.63 & 17.56 \\
\hline Sale and repair of motor vehicles and motorcycles & -52.86 & -52.99 & 0.29 \\
\hline Travel agency, tour operator reservation service and related activities & -51.68 & -56.82 & 11.83 \\
\hline Wholesale trade and commission trade & -47.14 & -50.98 & 7.78 \\
\hline Postal and courier activities & -41.40 & -55.16 & 30.59 \\
\hline Warehousing and support activities for transportation & -37.89 & -41.37 & 5.84 \\
\hline Real estate activities & -24.22 & -10.25 & -15.22 \\
\hline other personal service activities & -16.01 & -4.75 & -11.97 \\
\hline Land transport & 6.94 & -5.91 & 13.66 \\
\hline Accommodation services; food and beverage services & 27.11 & 17.62 & 7.84 \\
\hline Activities of membership organisations & 69.17 & 60.88 & 5.21 \\
\hline Rental and leasing activities & 94.52 & 87.50 & 3.61 \\
\hline Activities of households as employers & - & - & 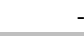 \\
\hline
\end{tabular}

Note: Within each group, the sectors are ordered from the lowest to highest rate of change of the II/Y ratio, that is, from the greatest to least incidence of reshoring between 2008 and 2010.

Source: Own elaboration based on the Input-Output Tables of Spain's National Accounts, INE. 


\section{Reshoring of services: effects on employment}

As indicated, there is no empirical evidence on the impact that the reshoring phenomenon has on the level of employment. Neither has the reshoring strategy been incorporated into the theoretical study within the framework of international trade models, (Olsen, 2006;

Blinder, 2006; Grossman and Rossi-Hansberg, 2006; Helpman, 2011; Melitz, 2003), or International Business literature (Dunning 1980a, 1980b, 1993, 2000; Lamb et al. 2011; Ellis, 2011; Laursen et al. 2012; Johanson and Wiedersheim-Paul, 1975; Johanson and Vahlne, 1977), which do incorporate the offshoring phenomenon. Therefore, there is no theoretical model that generates predictions about its possible effects. The empirical evidence on the reshoring phenomenon is focused on the analysis of its causes, but it is still insufficient to be able to verify whether the strategy is efficient in all cases. The results of the empirical studies indicate that the strategy is sometimes adopted to obtain efficiency to respond to changes in the economic environment that modify the predicted results of the offshoring strategy, and therefore prescribe the reversal of this strategy. But, in other cases, the offshoring strategy is reversed through reshoring due to problems of implementation based mainly on coordination failures. It may be surmised that in those cases in which an efficient decision is made that improves the allocation of resources, there should be a positive potential impact on employment as the increase in the use of national inputs and the reduction in foreign inputs could generate new jobs. And in the opposite case, when the strategy is not efficient, but is due to factors that oblige the companies to reverse the initial offshoring strategies, generating a loss of the advantages obtained with the original offshoring decision, improvements in their results, growth or the generation of employment cannot be expected.

Therefore, we have no analytical framework or empirical evidence that enables us to generate a hypothesis regarding the possible effects of the reshoring strategy on the level of employment when this strategy is implemented. However, we can distinguish possible transmission mechanisms between the reshoring strategy and the level of employment and also certain differences with the offshoring processes.

In the case of offshoring, the theoretical models predict positive effects on employment in the long term, as these strategies improve the competitiveness of the firms that implement them which should translate into long-term increases in production and therefore employment (Olsen, 2006; Blinder, 2006; Grossman and Rossi-Hansberg, 2006; Helpman, 2011; Melitz, 2003). However, short-term employment reductions are also 
produced, as jobs that are lost in the home country because they are replaced by the jobs generated by the activities transferred abroad. For this reason, the net effect of offshoring processes on employment is not determined theoretically, rather its assessment requires empirical estimations (Amiti and Wei, 2005, 2006 2009; Winkler, 2010; Michel and Rycx, 2012; Agnese, 2012; Wrigth, 2014; Fuster et al, 2019).

On the contrary, in the reshoring processes there are some differences in the possible transmission mechanisms in employment. First, if the reshoring strategy is efficient, unlike in the case of offshoring where the effects associated to employment are positive in the long term and negative in the short term, with reshoring the effects on employment should always be positive. The short-term effects should be positive due to the replacement of foreign jobs by domestic jobs and the long-term effects should also be positive as it is an efficient strategy. Second, only in the case where the strategy is inefficient, for example, due to faults in the implementation of the previous offshoring strategy, its net effect on employment would be a priori ambiguous. There would be a positive effect in the short term due to the replacement of foreign jobs by domestic jobs, but also negative effects in the long term because if the process is not efficient in the long term a loss of competitiveness would be generated together with a reduction in production and employment.

Methodologically, its measurement is similar to that of the offshoring strategy. And, therefore, the study of its effects is also similar.

The effects of offshoring on employment have been analysed with different data sources, with data on an industry level, a company level and more recently, with data on a worker level (Hummels, 2018). The methodology used in each case varies depending on the data source used.

For this reason, given that in this study a sectoral study is conducted on an industry level of the reshoring phenomenon, we will take as a reference the previous empirical evidence on the effects of offshoring of services on the level of employment based on sectoral data. We will only refer to the previous sectoral studies for the case of the offshoring of services.

These studies (Amiti and Wei, 2005, 2006 2009; Winkler, 2010; Michel and Rycx, 2012; Agnese, 2012; Wrigth, 2014; Fuster et al, 2019) estimate a log-linear labour demand function based on a homogeneous production function with constant economies of scale 
(CES), including, as a measurement of services offshoring, the proportion of imported service inputs with respect to the total inputs used, in some cases, and the total output in others. The results are positive in some cases and negative or null in others, but always of a very small size. Perhaps the explanation lies in the fact that although there is a growing trend in services offshoring levels in the periods in which the studies are carried out in all of the countries analysed, the scope in all cases is limited.

Furthermore, we should take into account the limitation that an analysis based on sectoral data has in the interpretation of the results. A shortcoming of using this methodology for calculating offshoring or reshoring indexes is that it provides results that are aggregated by sectors of activity. Therefore, in the analysis of the impact of these strategies on the level of employment, total net effects are obtained in the industries that could conceal positive or negative effects of the different companies that are included in each sector. In order to be able to estimate these effects on a microeconomic level, it would be necessary to carry out the study with data sources on a company level, but we do not have access to company databases regarding reshoring processes.

However, we can draw conclusions from the sectoral analysis based on the different results obtained in the empirical estimations, taking into account the possible compensation mechanisms between the companies belonging to each industry.

When the results show a positive effect for a whole sector of activity, it should be taken into account that perhaps not all of the companies in the sector generate this positive effect. For some, the effect will be positive, but for others it may be negative. Consequently, this positive result for an industry as a whole means that the positive effects of the companies that generate employment derived from implementing efficient reshoring processes dominate the negative effects of other companies associated to inefficient reshoring processes.

Finally, when the results show a negative effect for a sector as a whole, due to the compensation mechanisms described between the companies that belong to it, we could conclude that there may be positive effects for some companies and negative effects for others, but in this case those with negative effects are in the majority. In other words, the effects of inefficient reshoring processes are dominant in the sector. 


\section{Grouped model pool 2008-2010 in the years of reshoring and results}

After analysing the phenomenon of the reshoring of services in Spain, the second objective of this study is to analyse its impact on the level of employment.

As previously mentioned, in the Spanish economy a reshoring process of intermediate consumption of services began in the early years of the international economic crisis from 2008 to 2010. The economic crisis constituted one of the triggers of the reshoring process (Delis et al., 2019). In Spain, this process has been prominent in both the manufacturing and services sectors.

For this reason, this study analyses the impact that the phenomenon of the reshoring of services has had on employment in the years 2008, 2009 and 2010 in the Spanish economy. The analysis is conducted for manufacturing and for services. To do this, we have used the Input Output Tables of Spain's National Accounts for the Spanish National Statistics Institute (INE) for these years.

In the same way as the above-mentioned studies, we have estimated a log-linear labour demand function obtained from a homogeneous production function with constant economies of scale -CES- (Hamermesh, 1993), which also includes the dependence of important inputs of services as an explanatory variable. In previous studies, the evolution of this variable is positive and therefore called offshoring. However, given that in our estimate for the years analysed, 2008-2010, its evolution is negative, and we refer to it as reshoring $\left(\mathrm{R}_{\mathrm{i}}\right)$, although what is really included in the function is the index of inputs of imported services.

We conducted the estimation using Ordinary Least Squares, OLS, with the data pool for the whole period considered, 2008, 2009 and 2010, with clustered standard errors and including sectoral control dummies in order to test the robustness of the model.

The equation estimated in the case of manufacturing is [1], while in services we used the equation [2].

$$
L_{i}=\beta_{0}+\beta_{1} Y_{i}+\beta_{2} w_{i}+\beta_{3} R_{i}+\beta_{4} M T+\beta_{5} H T+v_{i}
$$

$i=1 \ldots . . n$, where $n$ is the number of observations. 


$$
L_{i}=\beta_{0}+\beta_{1} Y_{i}+\beta_{2} w_{i}+\beta_{3} R_{i}+\beta_{4} H K I S+\beta_{5} M K I S+\beta_{6} F K I S+\beta_{7} O K I S+v_{i}
$$

$L i=$ Total employment in logarithms; $Y i=$ value of production in logarithms; wi= average wage in logarithms; $R i=$ Reshoring of services and $v_{i}=$ random disturbance.

In order to group the dummy variables, we used the classification carried out in Section 4. Therefore, for the sectoral dummies in the case of manufacturing, three groups were taken: High-technology (HT); Medium-technology (MT); and Low-technology (LT), with the latter being the reference category in equation [1]

For services, the dummies are grouped into 5 categories: High-tech knowledge-intensive services (HKIS), Knowledge-intensive market services -excluding financial intermediation and high-tech services- (MKIS), Knowledge-intensive financial services (FKIS), Other knowledge-intensive services (OKIS) and Low Knowledge-intensive services (LKIS), the latter being the category of reference in equation [2].

With regard to the basis of the economic theory, the estimated value of the coefficient $\beta_{l}$, elasticity production-employment, should have a positive sign and the coefficient $\beta_{2}$, elasticity wage-employment, a negative sign. With respect to the coefficients estimated for reshoring $\beta_{3}$, in the same way as Wright (2011) and Agnese (2012) in the offshoring analysis, reshoring is not estimated in logarithms. In this case, the coefficient obtained $\beta_{3}$ is interpreted as employment semi-elasticity with respect to reshoring, and we seek to obtain its significance, quantity and sign.

Furthermore, in order to observe the effect on employment of including the reshoring of services, considered in its two forms of measurement and the effect of including reshoring or not on wage-employment and production-employment elasticities, the following three regressions are estimated for the period considered for each subsector, manufacturing and services:

(1) A labour demand function in which we do not include reshoring.

(2) A labour demand function in which we include reshoring as a regressor (R1) measured as the proportion of imported inputs (II) of the value of production (Y) 
(3) A labour demand function in which we include reshoring as an explanatory variable (R2) measured as the proportion of imported inputs (II) of total inputs, both domestic and imported (TI).

We performed the estimation using Ordinary Least Squares, OLS, with the data pool for the whole period considered, 2008, 2009, 2010, with clustered standard errors and including sectoral control dummies. The results obtained are presented in table 4 for the different samples considered.

Table 4: Labour demand estimate, pool 2008-2010

\begin{tabular}{|c|c|c|c|c|c|c|}
\hline & \multicolumn{3}{|c|}{ Manufacturing } & \multicolumn{3}{|c|}{ Services } \\
\hline & (1) & (2) & (3) & (1) & (2) & (3) \\
\hline $\ln y$ & $\begin{array}{c}0.681 \\
(0.077)^{* * *}\end{array}$ & $\begin{array}{r}0.687 \\
(0.076)^{* * *}\end{array}$ & $\begin{array}{c}0.681 \\
(0.078)^{* * *}\end{array}$ & $\begin{array}{r}0.995 \\
(0.095)^{* * *}\end{array}$ & $\begin{array}{c}0.977 \\
(0.092)^{* * *}\end{array}$ & $\begin{array}{r}0.993 \\
(0.094) * * *\end{array}$ \\
\hline $\ln w$ & -3.236 & -3.230 & -3.238 & -1.863 & -1.773 & -1.845 \\
\hline $\mathrm{m}$ & $(0.614)^{* * *}$ & $(0.596)^{* * *}$ & $(0.629)^{* * *}$ & $(0.124)^{* * *}$ & $(0.147)^{* * *}$ & $(0.137)^{* * *}$ \\
\hline $\mathrm{R} 1$ & & $\begin{array}{c}0.022 \\
(0.035)\end{array}$ & & & $\begin{array}{r}-0.021 \\
(0.012)\end{array}$ & \\
\hline $\mathrm{R} 2$ & & & $\begin{array}{l}0.001 \\
(0.010)\end{array}$ & & & $\begin{array}{r}-0.002 \\
(0.007)\end{array}$ \\
\hline HKI & & & & 0.441 & 0.400 & 0.439 \\
\hline$S$ & & & & $(0.285)$ & $(0.300)$ & $(0.289)$ \\
\hline MKI & & & & 0.471 & 0.452 & 0.474 \\
\hline $\mathrm{S}$ & & & & $(0.173)^{* * *}$ & $(0.173)^{* *}$ & $(0.171)^{* * *}$ \\
\hline FKI & & & & 0.332 & 0.306 & 0.334 \\
\hline$S$ & & & & $(0.328)$ & $(0.311)$ & $(0.329)$ \\
\hline OKI & & & & 0.719 & 0.656 & 0.709 \\
\hline$S$ & & & & $(0.222)^{* * *}$ & $(0.238)^{* * *}$ & $(0.235)^{* * *}$ \\
\hline MT & $\begin{array}{c}0.374 \\
(0.198)^{*}\end{array}$ & $\begin{array}{c}0.374 \\
(0.203)^{*}\end{array}$ & $\begin{array}{c}0.374 \\
(0.201)^{*}\end{array}$ & & & \\
\hline HT & $\begin{array}{c}0.701 \\
(0.273)^{* *}\end{array}$ & $\begin{array}{c}0.705 \\
(0.273)^{* *}\end{array}$ & $\begin{array}{c}0.701 \\
(0.279)^{* *}\end{array}$ & & & \\
\hline _con & 9.115 & 8.978 & 9.113 & 1.638 & 1.592 & 1.617 \\
\hline $\mathrm{S}$ & $(2.213)^{* * *}$ & $(2.045)^{* * *}$ & $(2.217)^{* * *}$ & $(0.849)^{*}$ & $(0.848)^{*}$ & $(0.879)^{*}$ \\
\hline$R^{2}$ & 0.880 & 0.881 & 0.880 & 0.868 & 0.871 & 0.868 \\
\hline$N$ & 54 & 54 & 54 & 114 & 114 & 114 \\
\hline
\end{tabular}

Dependent variable, $L i=$ Total employment in logarithms. Note: LT reference category in manufacturing; LKIS reference category in services. $* p<0.1 ; * * p<0.05 ; * * * p<0.01$. Clustered standard errors in parentheses. Source: Own elaboration based on the data of the input output tables (2008-2010) INE. 
The coefficients of production and the average wage correspond to their respective elasticities and the expected signs are obtained. Therefore, the coefficient $\beta_{1}$, productionemployment elasticity has a positive sign and the coefficient $\beta_{2}$, wage-employment elasticity has a negative sign, expressing the inverse relationship between wages and the level of employment.

With respect to our variable of interest, reshoring, there does not seem to be a significant relationship between employment and $\mathrm{R} 1$ and between employment and $\mathrm{R} 2^{3}$. As the coefficient is not significance there is no evidence that reshoring influences employment in the two samples, services and manufacturing.

Furthermore, differences are not found in $\beta_{1}$, production-employment elasticity or in $\beta_{2}$, wage-employment elasticity between the regressions (1)-(2) and (1)-(3) comparing the inclusion or not of reshoring. Only in the case of the inclusion of R1 in services, regression (2), can we observe a slight reduction in wage-employment elasticity. This could suggest that in some way, the reshoring carried out during these years mitigates the effect of wages on employment.

With respect to manufacturing, the sectoral dummies included in the model show that the coefficients of the MT and HT sectors are significant and positive, with the HT sectors being those with a higher coefficient. In services, we can observe that the sectoral dummies included are all positive, although only the MKIS and OKIS sectors are significant and have higher coefficients.

\section{Discussion and concluding remarks}

The reshoring of services has hardly been analysed in the economic literature. This paper contributes to the advancement of knowledge in this line of research, studying for the first time the service reshoring entity and its impact on the level of employment in the Spanish economy during the period 2008 to 2010.

\footnotetext{
${ }^{3}$ The correlations between employment and R1 and between employment and R2, are very low in the case of manufacturing, 0.08 and 0.11 , respectively. In the case of services, the correlations are also low, 0.30 between employment and R1 and 0.24 between employment and R2.
} 
The empirical study of the phenomenon reveals that, although in the period 2000 to 2008 there was an increasing trend in the offshoring of services strategy in Spain, this contrasts with the existence of a process of reshoring of services from the onset of the economic crisis. While the service offshoring strategy has been more intense in the service sector, the reshoring of services strategy has been more pronounced in manufacturing. Furthermore, the results reveal that between 2008 and 2010 the reduction of imported intermediate services was replaced by internal production in the manufacturing companies and by domestic external suppliers in the services sector.

The reshoring phenomenon observed between 2008 and 2010 is a reflection of the collapse of global trade caused by the international financial crisis in 2008 and 2009. The strong impact of this strategy on Spain was mitigated slightly by a new increase in the content of imported intermediate services between 2010 and 2015, mainly in the services sector, while that in manufacturing was practically insignificant. Although the firms increased the hiring of intermediate services abroad slightly between 2010 and 2015, the dependence on foreign services in 2015 was much lower than in 2008. This indicates that a significant part of the activities that were returned to the home country from the beginning of the crisis were not offshored again.

The sectoral analysis reveals the existence of the reshoring of services between 2008 and 2010 in all manufacturing industries and the majority of service industries. When the manufacturing branches are classified according to their technological content, we can observe that the lower the technological content of the manufacturing branch, the greater the incidence of reshoring. On the other hand, not all of the services branches have undertaken reshoring, but different behaviours can be observed. Grouping the branches according to their knowledge intensity reveals that knowledge-intensive financial services (FKIS) are those that have recorded the highest level of reshoring, while hightech knowledge-intensive services (HKIS) are those that have least reduced their dependence on imported intermediate services. All of the branches in these two groups have practised reshoring of services, contrary to the case of the other groups. These results are coherent with the empirical evidence on offshoring. It is known that the companies with higher technological capacities are those that most hire highly specialised services abroad that complement their internal activities in the home country (Jabbour and Zuniga, 2016; Tamayo and Huergo, 2016; Musteen, 2016; Holl and Rama, 2014; García-Vega and Huergo, 2011). The greater connection of these sectors with 
international markets could explain this lower tendency to undo these offshoring operations.

We have not obtained a significant relationship between employment and our variable of interest, reshoring. Therefore, there is no evidence that reshoring influences employment.

We should remember that the period considered was characterised by huge job destruction in Spain, particularly among low-skilled workers, with the Spanish labour market being highly sensitive to adjustments through the reduction of employment due to its high temporary rate.

These results show that the phenomenon of the reshoring of services in Spain was important during the early years of the economic crisis with levels of over $23 \%$ in manufacturing and $29 \%$ in services. They also reveal that the effects of this process on employment are not obvious. This highlights that the phenomenon can respond to different causes that should be analysed in depth so that we can gain a thorough understanding of its consequences and not turn to simplistic statements that are often spread by public opinion and certain political leaders which can lead to economic or trade policy measures with implications that are contrary or out of line with those expected.

\section{Future research}

This study is based on sectoral data and provides empirical evidence of the process of reshoring of services in Spain and its impact on the level of employment during the recent economic crisis.

Studies of this type provide precise information about the importance of the phenomenon and its impact on a factor that generates most concern among governments and public opinion in general, that is, employment.

Future research should be aimed at complementing this study in the business environment. In addition to the studies already published on reshoring with company data that study the causes of reshoring, future research could focus on analysing the effects of this strategy on employment and other relevant variables related to competitiveness. To this end, the different types of reshoring according to their causes would have to be analysed in greater depth and those operations of services reshoring that are efficient or inefficient would have to be identified. Once this differentiation has been established the 
consequences can be analysed. As the findings of this study show, the effects of this process are not obvious. Therefore, it is important to understand them before designing policies that foster these strategies with assumed pre-established objectives.

\section{References}

Afuah, A. (2001). Dynamic boundaries of the firm: are firms better off being vertically integrated in the face of a technological Change? Academy of Management Journal, 4(4): 1211-1228.

Albertoni, F., Elia, S., Fratocchi, L., Piscitello, L. (2015). Returning from Offshore: What do we know? AIB Insights, 15(4): 9-12.

Albertoni, F., Elia, S., Massini, S., Piscitello, L. (2017). The Reshoring of Business Services: Reaction to failure or persistent strategy? Journal of World Business, 52, 417430.

Agnese, P. (2012). Employment effects of offshoring across sectors and occupations in Japan. Asian Economic Journal. 26 (4): 289-311.

Amiti, M. and Wei, S.J. (2005). Fear of service outsourcing: is it justified? Economic Policy 20 (42): 308-347, http://dx.doi.org/10.1111/j.1468-0327.2005.00140.x.

Amiti, M. and Wei, S.J. (2006). Service offshoring and productivity: Evidence from the United States. National Bureau of Economic Research, Working Paper 11926, Cambridge, MA.

Amiti, M. and Wei, S.J. (2009). Does service offshoring lead to job losses? Evidence from the United States. In Marshall Reinsdorf and Metthew Slaughter (Ed.), International Trade in Services and Intangibles in the Era of Globalization (pp. 227-243). Chicago and London: University of Chicago Press.

Ariffin, N. (2000). The globalization of innovative capabilities: The Malaysian electronics industry. Science and Technology Policy Research. University of Sussex, Brighton.

Ariffin, N. and Figueiredo, P.N. (2006). Globalisation of innovative capabilities: Evidence from local foreign firms in the electronics industry in Malaysia and Brazil. Science, Technology and Society, 11(1), 191-227. 
Arlbjørn, J.S. and Mikkelsen, O.S. (2015). Backshoring manufacturing: Notes on an important but under-researched theme. Journal of Purchasing \& Supply Management, 20, 60-62.

Bailey, D. and De Propris, L. (2014). Manufacturing reshoring and its limits: the UK automotive case. Cambridge Journal of Regions, Economy and Society, 7, 379-395.

Baldwin, R. and Taglioni, D. (2009). The great trade collapse and trade imbalances. In Baldwin (Ed.), The great trade collapse: causes, consequences and prospects. Centre for Economic Policy Research (CEPR). A VoxEU.org Publication, November 2009.

Baldwin R., Forslid, R. and Ito, T. (2015): Inveiling the evolving sources of value added in exports, IDE-JETRO Joint Research Program Series, 161.

Blinder, A.S. (2006). Offshoring: The next industrial revolution? Foreign Affairs, 85(82): $113-127$.

Bogliano, F., Guarascio, D. and Cirillo, V. (2018). The Dynamics of profits and wages: Technology, and Casson, M. (1976). The Future of the Multinational Enterprise. London: Homes and Meier.

Buckley, P. and Casson, M. (1976): The future of the Multinational enterprise. The Macmillan Press LTD. London.

Cadarso, M.A, Gómez, N., López, L.A. and Tobarra, M.A. (2008). The EU enlargement and the impact of outsourcing on industrial employment in Spain, 1993-2003. Structural Change and Economic Dynamics, 19, 95-108.

Cadarso, M.A., Gómez, N., López, L.A. and Tobarra, M.A. (2012). Offshoring components and their effect on employment: firms deciding about how and where. Applied Economics 44, 1009-1020.

Campa, J. and Goldberg, L.S. (1997). The evolving external orientation of manufacturing industries: Evidence from four countries. Economic Policy Review. 3(2): 53-81, http://dx.doi.org/10.3386/w5919.

Cano-Kollmann, M., Cantwell, J., Hannigan, T.J., Mudambi, R. and Song J. (2016). Knowledge connectivity: An agenda for innovation research in international business. Journal of International Business Studies, 47, 255-262. 
Castellani, D., De Benedictis, L. and Horgos, D. (2013). Can we really trust offshoring indices? Structural Change and Economic Dynamics, 25, 159-172. https://doi.org/10.1016/j.strueco.2012.10.001

Chaminade, C. and Barnard, H. (2012). Global innovation networks: Towards a taxonomy. DRUID conference. Copenhagen, June.

Chesbrough, H.W. (2006). Open innovation: A new paradigm for understanding industrial innovation. In: Chesbrough, H.W., Vanhaverbeke, W. and West, J. (Eds), Open innovation: Researching a new paradigm. Oxford University Press, Oxford.

Chiappini, R. (2012). Offshoring and export performance in the European automotive industry. Competition and Change, 16(4): 323-342.

Contractor, F.J., Kumar, V., Kundu, S.K. and Pedersen, T. (2010). Reconceptualizing the firm in a world of outsourcing and offshoring: the organizational and geographical relocation of high-value company functions. Journal of Management Studies, 47, 14171433.

Cooke, P. (2005). Regionally asymmetric knowledge capabilities and open innovation: exploring 'globalization 2' - a new model of industry organization. Research Policy, 34(8), 1128-1149.

Cuervo-Cazurra, A. and Narula, R. (2015). A set of motives to unite them all? Revisiting the principles and typology of internationalization motives. The Multinational Business Review, 23(1), 2-14.

Dachs, B. and Zanker, C. (2015). Backshoring of production activities in European Manufacturing. Munich Personal RePEc Archive, MPRA Paper 63868.

Delis, A., Driffield, N. and Temouri, Y. (2019). The global recession and the shift to reshoring: Myth or Reality? Journal of Business Research, 103, 632-643.

Dell'Agostino, L. and Nenci, S. (2018). Measuring patterns of specialization using trade in value added: The case of manufacturing in Italy. Applied Economics letters, 25(21), 1487-1492.

Di Mauro, C., Fratocchi, L., Orzes, G. and Sartor, M. (2018). Offshoring and backshoring: A Multiple case study analysis. Journal of Purchasing and Supply Management, 24, 108134. 
Díaz Mora C., Gandoy, R. and González, B. (2007). La Fragmentación internacional en las manufacturas españolas. Papeles de Economía Española, 112, 74-88.

Díaz Mora C., Gandoy, R. and González, B. (2018). Looking into global value chains: influence of foreign services on export performance. Review of world Economics. 154, 785-814.

Doh, J., Bunyaratavej, K. and Hahn, E.D. (2009). Separable but not equal: The location determinants of discrete services offshoring activities. Journal of International Business Studies, 40(6), 926-943.

Dunning, J.H. (1980a). Toward an eclectic theory of international production: some empirical tests. Journal of International Business Studies, 11(1), 9-31.

Dunning, J.H. (1980b). The eclectic (OLI) paradigm of international production: past, present and future. International Journal of the Economics of Business, 8(2), 173-190.

Dunning, J.H. (1993). Multinational Enterprises and the Global Economy. Harlow: Addison-Wesley.

Dunning, J.H. (2000). The Eclectic paradigm as an envelope for economic and business theories of MNE activity. International Business Review, 9(2), 163-190.

Ellis, P.D. (2011). Social ties and international entrepreneurship: opportunities and constrains affecting firm internationalization. Journal of International Business Studies, 42(1), 99-127.

Ellram, L.M., Tate, W.L. and Billington, C. (2008). Offshore outsourcing of professional services: A transaction cost economics perspective. Journal of Operations Management, $26,148-163$.

Ernst, D. (2005). Complexity and internationalization of innovations: why is chip design moving to Asia? International Journal Innovation Management, 9(!), 47-73.

Eurostat (2016): Glossary: Knowledge-intensive services (KIS), in https://ec.europa.eu/eurostat/statistics-explained/index.php?title=Glossary:Knowledgeintensive_services_(KIS) 
Eurostat (2018): Glossary: High-tech classification of manufacturing industries, in https://ec.europa.eu/eurostat/statistics-explained/index.php/Glossary:Hightech_classification_of_manufacturing_industries

Feenstra, R.C. (1998). Integration of trade and disintegration of production in the global economy. Journal Economic Perspectives, 12, 31-50.

Feenstra, R.C. and Hanson, G. (1996). Globalization, outsourcing and wage inequality. American Economic Review, 86, 240-45.

Feenstra, R.C. and Hanson, G.H. (1999). The impact of outsourcing and high-technology capital on wages: estimates for the United States, 1979-1990. The Quarterly Journal of Economics 114, 907-940.

Fratocchi, L., DiMauro, C., Barbieri, P., Nassimbeni, G. and Zanoni, A. (2014). When manufacturing moves back: Concepts and questions. Journal of Purchasing and Supply Management, 20, 54-59.

Fuster, B. and Martínez-Mora, C. (2012). El offshoring de servicios como estrategia de competitividad. Economistas, 130, 96-107.

Fuster, B. and Martínez-Mora, C. (2013). Offshoring of services in Spain: international fragmentation of activities or change in procurement sources? Estudios de Economía Aplicada, 31 (2), 1-22.

Fuster, B., Martínez-Mora, C. and Pardo, G. (2008). Las estrategias de competitividad de la industria de calzado ante la globalización. Revista de Estudios Regionales, 86, 71-96.

Fuster, B., Lillo-Bañuls, A. and Martínez-Mora, C. (2019). The effects of service offshoring on employment. Structural Change and Economic Dynamics, 51, 529-538.

Gandoy, R., Díaz-Mora, C. and González-Díaz, B. (2018). El papel de los servicios en las cadenas globales de valor de las manufacturas. Papeles de Economía Española, 158, 139-153.

García-Vega, M. and Huergo, E. (2011). Determinants of international R\&D outsourcing: The role of trade. Review of Development Economics, 15(1): 93-107. 
Grossman, G.M., and Rossi-Hansberg, E. (2006). The rise of offshoring: It's not wine for cloth anymore. In Federal Reserve Bank of Kansas City (Ed.), The New Economic Geography: Effects and Policy Implications, (pp. 59-102). Denver (US).

Hechscher, E. and Ohlin, B. (1991). Heckscher-Ohlin Trade Theory. Cambridge: MIT Press.

Helpman, E. (2011). Understanding Global Trade, Harvard University Press.

Holl, A. and Rama, R. (2014). Foreign subsidiaries and technology sourcing in Spain. Industry and Innovation, 21(1): 43-64.

Hummels, D., Ishii, J. and Kei-Mu Yi (2001). The nature and growth of vertical specialization in word trade. Journal International Economics, 54(1): 75-96.

Hummels, D., Munch, J. and Xiang, C. (2018). Offshoring and labor markets. Journal of Economics Literature, 56(3): 981-1028.

Jabbour, L. and Zuniga, P. (2016). The outsourcing of research and development in global markets: Evidence from France. The World Economy, 39(3): 339-368.

Johansson, M. and Olhager, J. (2018). Comparing offshoring and backshoring: The role of manufacturing site location factors and their impact on post-relocation performance. International Journal of Production Economics, 205, 37-46.

Johanson, J. and Valhne, J.E. (1977). The internationalization process of the firm. A model of knowledge development and increasing foreign market commitments. Journal of International Business Studies, 8(1), 23-32.

Johanson, J and Wiedersheim-Paul, F. (1975). The internationalization of the firm. Four Swedish cases. Journal of Management Studies, 12(3), 305-323.

Kinkel, S., Lay, G. and Maloca, S. (2007). Development, motives and employment effects of manufacturing offshoring of German SMEs. International Journal Entrepreneurship and Small Business, 4(3), 256-276.

Koopman, R, Wang, Z. and Wei, J. (2014). Tracing value added and double counting in gross exports. American Economic review, 104(2), 459-494.

Krugman, P. (2009). The increasing returns revolution in trade and geography. American Economic Review, 99(3): 561-571. 
Lall, S. (1993). Promoting technology development: the role of technology transfer and indigenous effort. Third World Q., 14(1), 95-108.

Lamb, P., Sandberg, J. and Liesch, P.W. (2011). Small firm internationalization unveiled through phenomenography. Journal of International Business Studies, 42(5), 672-693.

Lanz, R. y Maurer, A. (2015): Services and Global Value Chains: Servicification of Manufacturing and Services Networks, Journal of International Commerce, Economics and Policy, 6 (3). https://doi.org/10.1142/S1793993315500143

Laursen, K., Masciarelli, F. and Prencipe, A. (2012). Trapped or spurred by the home region? The effects of potencial social capital on involvement in foreign markets for goods and technology. Journal of International Business Studies, 43(9), 783-807.

Lema, R., Quadros, R., Hubert, S. (2015). Reorganising global value chains and building innovation capabilities in Brazil and India. Research Policy, 44, 1376-1386.

Lewin, A.Y., Massini, S., Peeters, C. (2009). Why are companies offshoring innovation? The emerging global race for talent. Journal International Business Studies, 40(6), 901925.

Martínez-Mora, C. and Merino, F. (2014). Offshoring in the footwear industry: A return journey? Journal of Purchasing and Supply Management, 13, 137-151.

Martínez-Mora and Merino, F. (2017). La estrategia de retorno de la industria española: El caso del sector calzado en Alicante, su importancia y determinantes. Estudios de Economía Aplicada, 35(3): 777-800.

Martínez-Mora and Merino, F. (2019). The impact of offshoring on firm's exports. Revista de Economía Mundial, 53, 203-222.

Martínez-Noya, A., García-Canal, E. and Guillen, M.F. (2012). International R\&D service outsourcing by technology-intensive firms: Whether and where? Journal of International Management, 18, 18-37.

Mclvor, R. (2013). Understanding the manufacturing location decision: the case for the transaction cost and capabilities perspectives. Journal of Supply Chain Management, 49, 23-26. 
Melitz, M.J. (2003). The impact of trade in intra-industry reallocations and aggregate industry productivity. Econometrica, 71(6), 1695-1725.

Michel, B. and and Rycx, F. (2012). Does offshoring of materials and business services affect employment? Evidence from a small open economy. Applied Economics, 44, 229251.

Moser, C., Urban, D. and Di Mauro, B. (2015). On the heterogeneous employment effects of offshoring: Identifying productivity and downsizing channels. Economic Inquiry, 53 (1): 220-239.

Mudambi, R. and Venzin, M. (2010). The strategic nexus of offshoring and outsourcing decisions. Journal of Management Studies, 47(8), 1510-1533.

Musteen, M. (2016). Behavioral factors in offshoring decisions: A qualitative analysis. Journal of Business Research, 69, 3439-3446.

Nordås, H. and Y. Kim (2013), "The Role of Services for Competitiveness in Manufacturing", OECD Trade PolicyPapers, No. 148, OECD Publishing, Paris.http://dx.doi.org/10.1787/5k484xb7cx6b-en

OECD (2014), "Global Value Chains: Challenges, Opportunities, and Implications for Policy", Report prepared for submission to the G20 Trade Ministers Meeting Sydney, Australia, 19 July 2014: OECD, WTO, and the World Bank.

Olsen, K., 2006. Productivity impacts of offshoring and outsourcing: A review. OECD Science, Technology and Industry Working Papers, 2006/01, OECD Publishing. Paris, http://dx.doi.org/10.1787/685237388034.

Orberg Jensen, P. and Pedersen T. (2011). The economic geography of offshoring: the fit between activities and local context. Journal of Management Studies, 48(2), 352-372.

Pahl, S., Marcel P., Timmer (2019). Do global value chains enhance economic upgrading? A long view. The Journal of development Studies, 42, 1-23.

Parmigiani, A.E. (2007). Why do firms both make and buy? An investigation of concurrent sourcing. Strategic Management Journal. 28, 285-311. 
Pavit, K. and Patel, P. (1999). Global corporations and national systems of innovation: who dominates whom? In Archibugi, D., Howels, J. Michie, J. (Eds.), Innovation Policy in a Global Economy. Cambridge University Press, Cambridge, pp. 94-119.

Petricevic, O. and Teece, D.J. (2019). The structural reshaping of globalization: Implications for strategic sectors, profiting from innovation, and the multinational enterprise. Journal of international Business Studies, 50, 1487-1512.

Pilat, D. and Wölfl, A. (2005), "Measuring the Interaction between Manufacturing and Services", OECD Science, Technology and Industry Working Papers, 2005/05, OECD. Publishing. http://dx.doi.org/10.1787/882376471514

Ricardo, D. (1817). On the Principles of Political Economy and Taxation. London: John Murray.

Rothaermel, F.T., Hitt, M.A. and Jobe, L.A. (2006). Balancing vertical integration and strategic outsourcing: Effects on product portfolio, product success, and firm performance. Strategic Management Journal, 27(11): 1033-1056.

Rugman, A.M. (1981). Inside the multinationals: The economics of internal markets. New York: Columbia University Press.

Shih, W. (2013). The resurgence of manufacturing in America. Inside Supply Management, 4(5): 30-33.

Serrano, J. and Myro, R. (2019). Management, productivity and heterogeneity in international trade. Applied Economic Analysis, vol. ahead of print, pp. 2632-7627.

Simard, C. and West, J. (2006). Knowlwdge networks and the geographic locus of innovation. In: Chesbrough, H.W., Vanhaverbeke, W. and West, J. (Eds), Open innovation: Researching a new paradigm. Oxford University Press, Oxford.

Solaz, M. (2018). Value added and participation in global value chains: The case of Spain. The World Economy, 41(10), 2804-2827.

Stentoft, J., Olhager, J., Heikkilä, J. and Thoms, L. (2016). Manufacturing backshoring: A systematic literature review. Operations Management Research, 9(3): 53-61.

Tamayo, M.P. and Huergo, E. (2016). Determinants of internal and external R\&D offshoring: Evidence from Spanish firms. Industry and Innovation, 24(2):143-164. 
Tate, W.L. (2014). Offshoring and reshoring: U.S. insights and research challenges. Journal of Purchasing and Supply Management, 20(1): 66-68.

Tate, W.L., Ellram, L.M., Schoenherr, T. and Petersen, K.J. (2014). Global competitive conditions driving the manufacturing location decision. Business Horizons, 57(3): 381390.

Timmer, M.P.; Los, B.; Stehrer, R. and Vries, G.J. (2016). An Anatomy of the Global Trade Slowdown based on the WIOD 206 Relaese. Groningen Growth and development Centre research memorandum 162, University of Groningen, November.

Vecchi, A. (2017). Reshoring of manufacturing. Drivers, opportunities and challenges. Springer International Publishing AG. Switzerland. DOI https://doi.org/10.1007/978-3$\underline{319-58883-4}$

Wagner, J. (2011). Offshoring and firm performance: Self-selection, effects on performance, or both? Review of World Economics, 147, 217-247.

Winkler, D., 2010. Services offshoring and its impact on productivity and employment: evidence from Germany, 1995-2006. World Economy, 33(12):1672-1701.

Wrigth, G., 2014. Revisiting the employment impact of offshoring. European Economic Review, 66, 63-83.

Zhang K.H. (2003). China as the Word Factory. Routledge Studies in the Growth Economies of Asia. Abingdon: Routledge. 